\title{
Photosynthesis and shoot water status of seedlings from different oak species submitted to waterlogging
}

\author{
E Dreyer ${ }^{1 *}, M$ Colin-Belgrand $2, P$ Biron 2 \\ 1 Laboratoire de Bioclimatologie et d'Ecophysiologie Forestière, \\ INRA Nancy, Champonoux, 54280 Seichamps; \\ 2 Laboratoire d'Étude des Sols et de la Nutrition, INRA Nancy, Champenoux, \\ 54280 Seichamps, France
}

(Received 16 August 1990; accepted 8 January 1991)

\begin{abstract}
Summary - Stress effects induced on shoot photosynthesis and leaf water status by root hypoxia due to waterlogging have been assessed on saplings of Quercus robur, $Q$ petraea, $Q$ rubra and $Q$ palustris in 2 successive experiments. Daily (first experiment) and weekly (second experiment) measurements of leaf gas exchange were made during 2 and 7 wk of waterlogging with a water table at 3 (1st) and $6 \mathrm{~cm}$ below the soil surface (2nd experiment). Net $\mathrm{CO}_{2}$ assimilation rate (A), and leaf conductance to $\mathrm{CO}_{2}(\mathrm{~g})$ were rapidly and strongly affected by waterlogging in almost every case. $\mathrm{CO}_{2}$ diffusion analysis of gas exchange data revealed that both stomatal and non stomatal limitations apparently induced this decline. Predawn leaf water potential remained high in all cases, indicating that reductions in photosynthesis were not due to altered leaf water status. Possible mechanisms relating root hypoxia and leat physiology are discussed. Within this general framework, some species-related differences could be detected: reactions of $Q$ robur were in general much more limited than those of $Q$ rubra and $Q$ palustris, being virtually absent when the water table remained at 6 $\mathrm{cm}$ below soil surface. This observation could be connected with the ability of $Q$ robur to produce more adventitious roots when waterlogged. No significant long term trend parallelling phases of root decay and subsequent root regeneration could be observed in photosynthesis for this species.
\end{abstract}

stomatal conductance / water potentlal / Quercus robur / Quercus petraea / Quercus palustrls / Quercus rubra

Résumé - Photosynthèse et état hydrique de jeunes semis de chênes soumis à un ennoyage. Nous avons analysé les effets d'une hypoxie racinaire due à un ennoyage sur la photosynthèse foliaire et l'état hydrique de jeunes plants de Quercus robur, Q petraea, Q rubra et $Q$ palustris au cours de 2 expériences successives. Des mesures quotidiennes (1re expérience) et hebdomadaires ( $2^{\circ}$ expérience) d'échanges gazeux ont été réalisées pendant 2 et 7 semaines d'ennoyage contrôlé, avec une nappe d'eau à 3 (1re expérience) el à $6 \mathrm{~cm}$ ( $2^{\circ}$ expérience) de la surface du sol. L'assimilation nette de $\mathrm{CO}_{2}(\mathrm{~A})$ et la conductance foliaire pour le $\mathrm{CO}_{2}(g)$ ont été trés fortement et rapidement réduites par la contrainte au cours des 2 expériences dans presque tous les cas. L'utilisation d'un modèle de diffusion du $\mathrm{CO}_{2}$ vers les tissus mésophylliens indique que les limitations observées seraient dues à des facteurs stomatiques et non stomatiques. Le potentiel hydrique de base est resté élevé pendant toute la phase d'ennoyage. De ce fait, les perturbations foliaires observées ne peuvent pas être expliquées par une degradation de l'état d'hydratation des tissus foliaires. La possibilité d'une intervention de métabolites racinaires est discutée. Un certain nombre de diffé-

- Correspondence and reprints 
rences entre espèces ont pu être détectées à lintérieur de ce cadre général. Q robur s'est révélé beaucoup moins sensible que $Q$ rubra et $Q$ palustris dans nos conditions. En particulier, les réductions de photosynthèse ont été pratiquement absentes au cours de la seconde expérience, avec une nappe à $6 \mathrm{~cm}$ de la surface. Ces différences peuvent être mises en parallèle avec les capacités de production de racines adventives de cette espece en conditions d'hypoxie. Cependant, l'alternance d'une phase de dégradation de racines et d'une phase de régénération racinaire intense ne s'est pas traduite par des fluctuations de la photosynthese foliaire.

hypoxie / ennoyage / assimilation nette / stomate / potentiel hydrique / Quercus robur / Quercus petraea / Quercus palustris / Quercus rubra

\section{INTRODUCTION}

Seedlings of different oak species ( $Q$ robur, $Q$ rubra and $Q$ palustris) display large differences in root reactions to waterlogging (Colin-Belgrand et al, 1991). In particular, waterlogged $Q$ robur seedlings exhibited important adaptive reactions, producing a large number of adventitious roots from the 4th week of treatment on, while those of $Q$ palustris and $Q$ rubra presented only limited root adaptations (ColinBelgrand et al, 1991). What are the consequences of these differences in root reactions on seedling physiology ? Are they accompanied by differences in patterns of shoot gas exchange?

Reactions of tree shoots to waterlogging and associated root hypoxia include strong decreases in $\mathrm{CO}_{2}$ assimilation rates (A) in almost every species studied (Childers and White, 1942; Regehr et al, 1975; Peterson and Bazzaz, 1984; Pezeshki and Chambers, 1985; Davies and Flore, $1986 a, b)$. These reductions even affect species with the highest degrees of tolerance such as Taxodium distichum ( $\mathrm{Pe}$ zeshki et al, 1986). Only very few reports of an absence of reaction have been published (Zaerr, 1983; with Pinus silvestris). These reductions in $A$ are generally accompanied by marked decreases in stomatal conductance (g) (Childers and White, 1942; Regehr et al, 1975; Tang and Koz- lowski, 1982; Pezeshki and Chambers, 1985, 1986; Savé and Serrano, 1986; Davies and Flore, 1986a, b; Harrington, 1987; Osonubi and Osundina, 1987; Smit and Stachowiak, 1990; Lewty, 1990), although Wample and Thornton (1984) reported decreasing $A$ without noticeable stomatal closure (Lycopersicon esculentum). These stress effects generally appear very rapidly, after a few d (even a few $h$ in some cases) of exposure to a degassed water table (Pezeshki and Chambers, 1985; $\mathrm{Pe}$ zeshki and Sundström, 1988; Smit and Stachowiak, 1990).

With respect to the important effects of flooding on root functions evidenced earlier, it was of primary importance to test possible correlations between root and shoot behaviour. Early effects of waterlogging may be mediated by root signals of different nature (Bradford, 1983). The subsequent strong decay of submerged roots and possible formation of adventitious transformed roots could have strong effects on photosynthesis and leaf water status. The contrasting behaviour of $Q$ robur and $Q$ rubra in this respect (ColinBelgrand et al, 1991) is an interesting basis, for experimental investigation.

Contrasting tolerance to waterlogging has only seldom been related to differences in the intensity of stress reactions at shoot level. Do all species suffer from the same magnitude of $A$ and $g$ impairment, as observations with fairly tolerant trees like 
Taxodium distichum (Pezeshki et al, 1986) seem to indicate, or are there some differences related to the degree of tolerance?

The aims of this study were: 1 ), to establish the nature and intensity of the reactions of $A$ and $g$ of oak seedlings to root hypoxia; 2 ), to test the possible correlations between root adaptations appearing during long term flooding, and shoot photosynthesis, leaf conductance to $\mathrm{CO}_{2}$ and water status; 3 ), to analyze the differences in the behavior of oak species with contrasting waterlogging tolerance $(Q$ robur, $Q$ petraea, $Q$ rubra and $Q$ palustris).

\section{MATERIALS AND METHODS}

Photosynthetic functions have been analyzed in 2 successive experiments. The first experiment aimed at assessing the effects of severe waterlogging conditions (water table at $3 \mathrm{~cm}$ below the soil surface). In this experiment special attention was paid to the short term (d) effects of waterlogging. In the second experiment, the effects of moderate waterlogging (water table at 6 $\mathrm{cm}$ below the soil surface) were tested. The duration of this experiment was long enough ( 7 wk) to allow seedlings to present potentially adventitious rooting and possible consequences on shoot gas exchange.

\section{Plant material and experimental set-up}

\section{Experiment 1}

Acorns were collected in the autumn of 1984 under adult trees of the following species: Quercus robur L (Amance Forest), $Q$ petraea (Matt) Lieb) (Villey St Etienne Forest) and $Q$ rubra $L$ (Brin sur Seille) all located near Nancy, north-easten France.

The acorns were stored at $-1{ }^{\circ} \mathrm{C}$ and sown during the following August in individual pots containing a $50 / 50 \mathrm{v} / \mathrm{v}$ mixture of peat/sandy loam. They were transplanted int $5-1,25-\mathrm{cm}$ deep pots with the same substrate in March, and were grown in a glasshouse near Nancy.
The pots were equipped with external transparent tubing allowing a precise control of water table level. Seedlings were $\approx 50 \mathrm{~cm}$ tall when the measurements were begun (July 1986).

The pots were flooded with tap water on July 18th. The upper water table level was maintained at $3 \mathrm{~cm}$ from soil surface by daily rewatering. The oxygen content of the water table, as measured with an oxygen electrode (Orbisphère 27141 ), reduced to $\approx 0.20 \mathrm{ppm}$. The pots were drained after $15 \mathrm{~d}$. The seedlings were kept in the greenhouse and gas exchange measurements were performed daily under controlled conditions. Three trees were used for each species.

A (net $\mathrm{CO}_{2}$ assimilation rate, $\mu \mathrm{mol} . \mathrm{m}^{-2} . \mathrm{s}^{-1}$ ) and $\mathrm{g}$ (equivalent leaf conductance to $\mathrm{CO}_{2}$, mmol. $\mathrm{m}^{-2} \cdot \mathrm{s}^{-1}$ ) were measured daily on the same leafy shoot of 3 seedlings per species. Plants were removed from the greenhouse just prior to the measurements. Three series of measurements were made daily from the day preceding waterlogging onwards. Each series consisted of 3 plants of a given species measured in parallel. The ranking of species was changed every day to limit artifacts related to diurnal variations in photosynthetic capacity. Each series of measurements lasted $\approx 2.5 \mathrm{~h}(1 \mathrm{~h}$ for the installation and removal of the plants and $1.5 \mathrm{~h}$ of equilibration to the chamber climate).

\section{Experiment 2}

Acorns were collected during the autumn of 1987, under individuals of $Q$ robur $L$ (Amance Forest), $Q$ rubra L (Fénétrange Forest, Moselle, France) and $Q$ palustris Muenchh (Pujo Forest, Hautes Pyrénées, France). Seedling preparation was carried out in February as indicated above, and measurements were made in July 1988. Height growth was monitored weekly. The growth conditions and soil characteristics have been described by Colin-Belgrand et al (1991).

The plants were waterlogged with tap water on June 15th. The upper level of the water table was adjusted daily to $6 \mathrm{~cm}$ from the soil surface, and was maintained during 7 wk. Sixty plants were used for each species, 30 randomly selected ones as controls and $\mathbf{3 0}$ as treated samples. Gas exchange was monitored weekly on 4 seedlings ( 3 treated and one control) which had been randomly selected at the beginning of the exper- 
iment. The remaining seedlings were used for weekly measurements of shoot and root growth, water potential, and mineral status in xylem sap and stems (see Colin-Belgrand et al, 1991).

$A$ and $g$ were measured weekly in the same shoot bearing 3-4 leaves of 4 seedlings per species ( 3 waterlogged and 1 control). Measurements were made in 4 series (waterlogged plants of each species plus 3 controls) on $1 \mathrm{~d}$ each week. The same design as in experiment 1 was used. The plants were measured once before, and 7 times during waterlogging. Problems in the measurement of transpiration affected our results during the first few weeks; these data were removed from the data set.

\section{Gas exchange measurements}

\section{Measuring device}

Net $\mathrm{CO}_{2}$ assimilation rates $(\mathrm{A})$ and total leaf conductance to $\mathrm{CO}_{2}(g)$ were measured in an open flow gas exchange system. The measuring device consisted of 3-altuglass assimilation chambers which were connected in parallel to the same main gas flow $\left(180 \mathrm{I}^{-1} \mathrm{~h}^{-1}\right)$. The $\mathrm{CO}_{2}$ molar fraction of the incoming air was measured with an ADC Mk II infrared gas analyzer, and maintained at $350 \mu \mathrm{mol} \cdot \mathrm{mol}^{-1}$ by injection of a $\mathrm{N}_{2} / \mathrm{CO}_{2} 90 / 10 \mathrm{v} / \mathrm{v}$ mixture into the main flow. The molar fraction of water vapour in the injected air was controlled by means of a dew point water trap. The temperature inside the chambers was controlled via Peltier cooled thermoelements. A multichannel valve allowed sequential analysis of the gas mixtures at the outlet of each chamber at 5 -min intervals. $A$ was computed from the difference measured in the $\mathrm{CO}_{2}$ molar fraction between incoming and outcoming air as monitored by an ADC Mk III infrared gas analyzer and from the molar air flow at the chamber inlet as derived from a volumetric flow meter. The transpiration rate (E) was estimated from the difference in the molar fraction of water vapor between incoming and outcoming air, as displayed by a dew-point hygrometer Elcowa western Electric $\left( \pm 0.1^{\circ} \mathrm{C}\right)$. Illumination was provided by 3 ( 1 for each chamber) sodium lamps (SONT Philips, $400 \mathrm{~W}$ ), and incident photosynthetic photon flux density (PPFD) was measured with a Li-Cor quantum sensor.
The climate was regulated as follows: air temperature (ta): $24 \pm 0.2{ }^{\circ} \mathrm{C} ; \mathrm{CO}_{2}$ molar fraction at the inlet: $350 \mu \mathrm{mol}^{-\mathrm{mol}^{-1}}$ and in the chamber $\left(c_{a}\right): 310 \pm 20 \mu \mathrm{mol} . \mathrm{mol}^{-1}$ depending on the rate of $A$; leaf to air difference in molar fraction of water vapor $(\Delta w): 12.0 \pm 1.5 \mathrm{~Pa}$ $\mathrm{kPa}^{-1}$; PPFD: $600 \pm 20 \mu \mathrm{mol} \cdot \mathrm{m}^{-2} \cdot \mathrm{s}^{-1}$. Total leaf area was measured with a planimeter. Each single measurement was preceded by a period of acclimation to the chamber atmosphere of 90 min. Calculations of total leal conductance $(g)$ and of intercellular $\mathrm{CO}_{2}$ molar fraction $\left(c_{i}\right)$ were made according to Ball (1988).

Results were represented as time courses of $A$ and $g$, or as $A$ vs $c_{i}$ diagrams displaying photosynthetic demand and supply functions (Jones, 1985; Guehl and Aussenac, 1987). Demand functions are defined as the $A / c_{i}$ relationship, and supply functions are straight lines joining the points $\left(0, C_{2}\right)$ and $\left(A, C_{i}\right)$; the slope of these lines is nearly equal to $-g$. On these diagrams we drew demand functions on the hypothesized basis of a linear relationship betwen $A$ and $c_{i}$ until $c_{i}=250 \mu \mathrm{mol} \cdot \mathrm{mol}^{-1}$.

\section{Measurements of water status}

Shoots of randomly selected plants (2 control and 2 treated per species) were cut off once weekly after being submitted to at least $12 \mathrm{~h}$ of darkness, and water potential $\left(\Psi_{w 0}\right)$ for the whole shoot was measured with a pressure chamber.

\section{RESULTS}

Waterlogging had a marked short term effect on net $\mathrm{CO}_{2}$ assimilation rate $(A)$, and leaf conductance to $\mathrm{CO}_{2}(g)$ in all species (fig 1, Exp 1); both $A$ and $g$ decreased rapidly in $Q$ robur, and after very few days in $Q$ petraea and $Q$ rubra. Some speciesrelated differences appeared: $Q$ robur had highest values of $A$ and $g$ before waterlogging but also showed the steepest decreases in both parameters between $d 0$ and 1, while $Q$ petraea maintained higher values during waterlogging. $Q$ rubra 


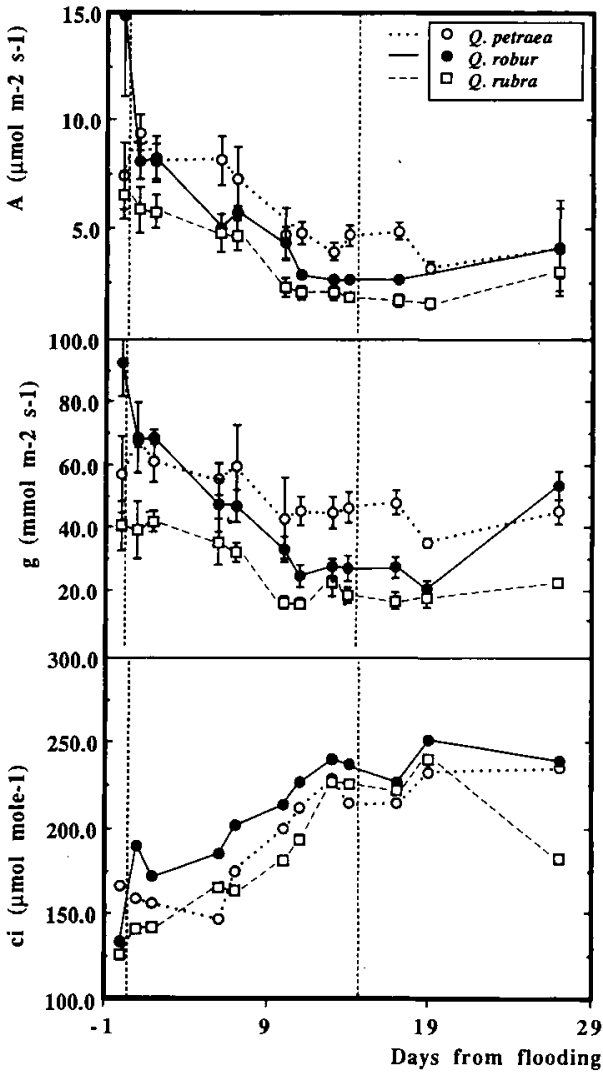

Fig 1. Effects of waterlogging on net $\mathrm{CO}_{2}$ assimilation rate $(A)$, total leaf conductance to $\mathrm{CO}_{2}$ $(g)$, and intercellular $\mathrm{CO}_{2}$ mole fraction $\left(c_{j}\right)$ of saplings of $Q$ petraea, $Q$ robur and $Q$ rubra. Vertical dotted lines indicate duration of waterlogging and subsequent drainage. Each point represents the mean of 3 measurements $( \pm S E)$. See text for climate conditions.

showed both low initial values and a strong reduction. Calculated values of $c_{i}$ increased regularly, reaching levels of $\approx 250$ $\mu \mathrm{mol} . \mathrm{mol}^{-1}$ at the end of the waterlogging period. After $12 \mathrm{~d}$ of drainage, recovery was very poor; only $Q$ robur showed significant but uncomplete recovery of $g$.

Representing the same set of data as $A$ $v s c_{i}$ diagrams yielded the graphs in figure 2. A demand function and a supply func-

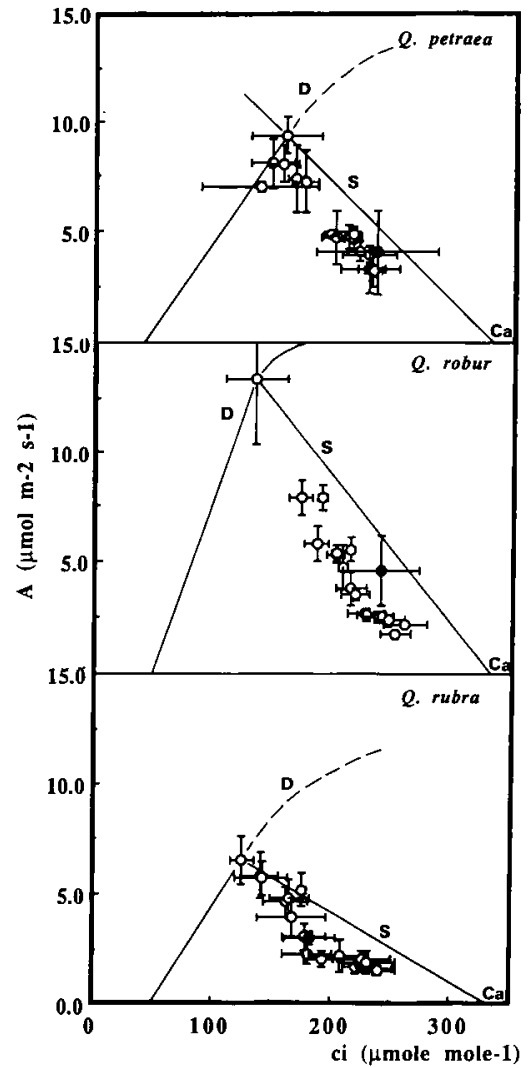

Fig 2. Effects of waterlogging on $A / c_{i}$ relationships: the evolution of net $\mathrm{CO}_{2}$ assimilation rate (A) during waterlogging and after recovery has been drawn as a function of corresponding values of intercellular $\mathrm{CO}_{2}$ mole fractions $\left(c_{i}\right)$. A set of hypothetical demand (D) and supply (S) functions (Jones, 1985, Guehl and Aussenac 1987) describing net assimilation prior to waterlogging has been drawn. Demand, $\operatorname{\theta g} c_{i}$ response curves are supposed to be linear up to $c_{i}$ values of $250 \mu \mathrm{mol} . \mathrm{mol}^{-1}$, and the compensation point is fixed at $\approx 50 \mu \mathrm{mol} . \mathrm{mol}^{-1}$. The black point is the measurement made $14 \mathrm{~d}$ after drainage. Vertical and horizontal bars represent the standard error of the mean for $A$ and $c_{i}(n=3)$.

tion joining $c_{a}=330 \mu \mathrm{mol} . \mathrm{mol}^{-1}$ and maximal $A$ (slope $\approx-g$ ) both describing the situation before waterlogging have been drawn. The observed decreases in $A$ fol- 


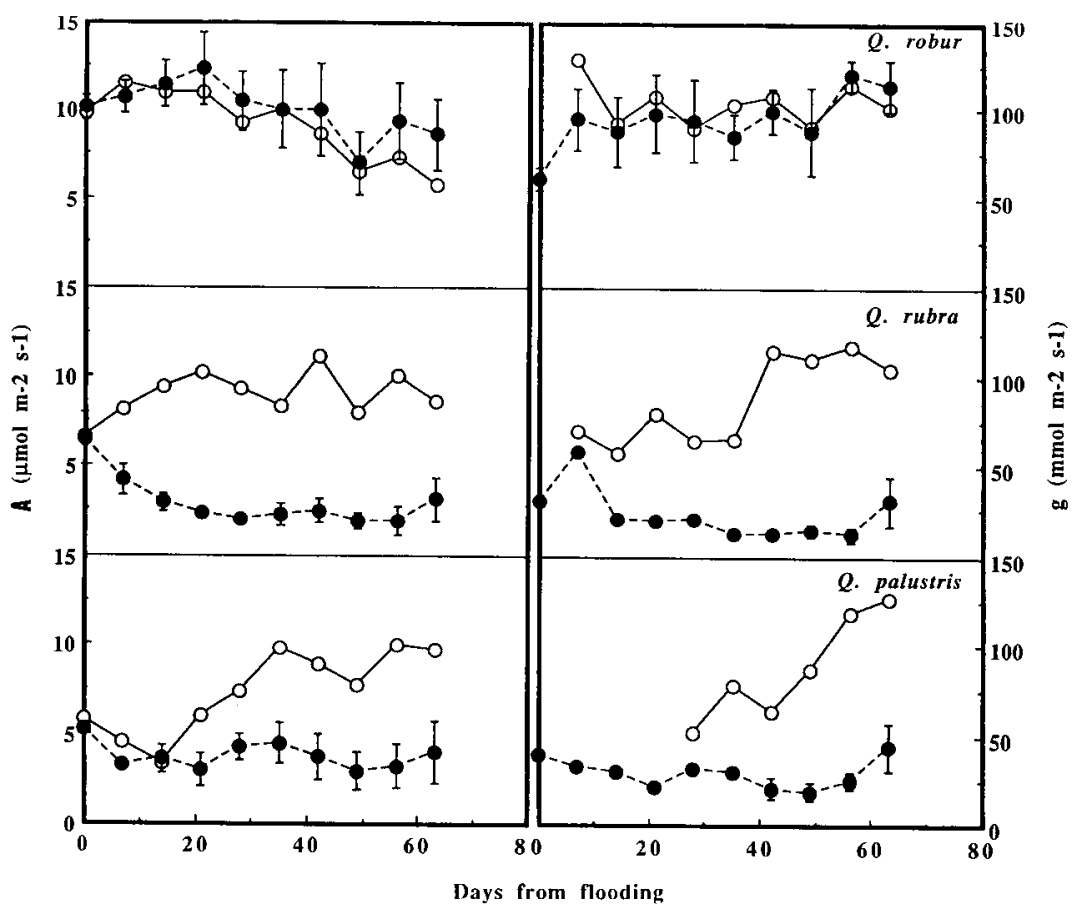

Fig 3. Time course of net $\mathrm{CO}_{2}$ assimilation rate $(A)$ and leaf conductance to $\mathrm{CO}_{2}(g)$ of control (open symbols, $n=1$ ) and waterlogged seedlings (closed symbols, $n=3$ ). Some values of $g$ are lacking because of technical defects in the measurement device. Measurements were made weekly on the same leaves during the entire experiment.

lowing waterlogging appeared to be due to both a decrease in leaf conductance $(g$, decrease of supply function slope), and an even stronger decrease in demand. After $12 \mathrm{~d}$ of drainage, demand functions did not recover in any species (dark points in fig 2).

During $\exp 2$, the evolution of net assimilation rate $(A)$ and leaf conductance to $\mathrm{CO}_{2}(g)$ as illustrated in figure 3 displayed some marked differences. For 2 species ( $Q$ rubra and $Q$ palustris), $A$ of control plants increased, while it decreased slightly in $Q$ robur. The same patterns appeared for $g$. Important differences among species appeared with regard to the waterlogging treatment. $Q$ robur showed almost no reaction to waterlogging: $A$ and $g$ for both control and treated seedlings evolved in parallel, and no difference could be detected at any stage. For $Q$ rubra, we observed a strong decrease in both $A$ and $g$ (less visible in $g$ due to lack of sufficient data). $Q$ palustris displayed an intermediate trend: we did not observe a strong decrease in $A$ or $g$, but the increase observed in the control seedling was completely suppressed.

Drainage following the 7 wk of waterlogging was not followed by recovery of $A$ or $g$ in $Q$ rubra and $Q$ palustris; only a slight increase in $g$ was observed.

Predawn leaf water potential $\left(\Psi_{w b}\right)$ of waterlogged and control plants, measured during exp 2, did not differ markedly during the entire waterlogging period (fig 4). A direct comparison of the mean values for 


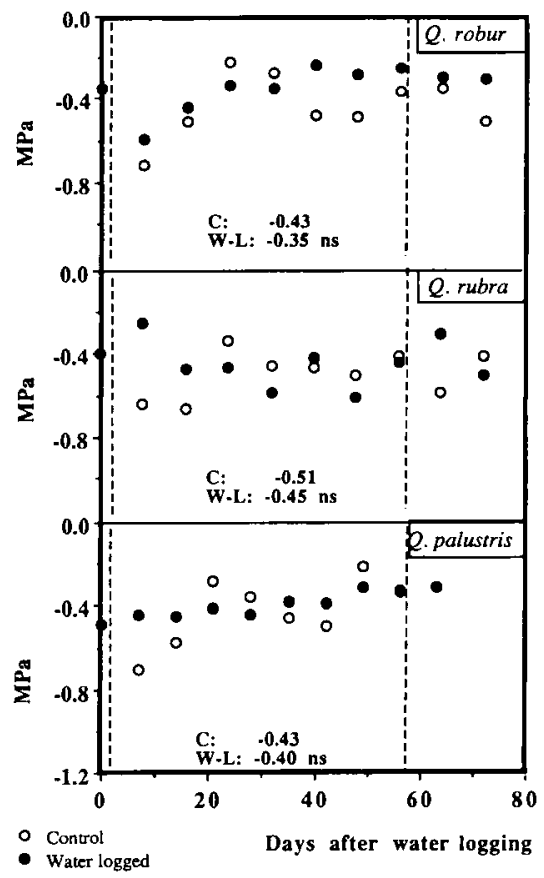

Fig 4. Predrawn leaf water potential $\left(\Psi_{w b}\right)$ of waterlogged (closed symbols) and control plants (open symbols) of the 3 oak species tested. Each point is the mean value of 2 seedlings. Numbers indicate the means of control and waterlogged during the whole period of waterlogging; differences were not significant for any species (Fisher PLSD, $n=14$ ).

control and waterlogged plants during the waterlogging period (Fisher PLSD, $n=14$ ) yielded the mean values indicated on the graphs: for none of the tested species were these differences statistically significant. $\Psi_{w b}$ was even slightly higher in flooded plants than in controls. Therefore, high levels of roots senescence observed in response to waterlogging on the same seedlings and described in Colin-Belgrand et al (1991) did not significantly alter leaf water status in any tested plant or species.

\section{DISCUSSION}

Many of the oak seedlings tested during these experiments presented significant reductions in net $\mathrm{CO}_{2}$ assimilation rates (A) and leaf conductance to $\mathrm{CO}_{2}(g)$ in reaction to root hypoxia induced by waterlogging. Short term reactions generally appeared after very few days of waterlogging with tap water. Analog reductions of $A$ and $g$ with the same precocity have been observed in a wide range of tree species including UImus americana (Newsome et al, 1982), Fraxinus pennsylvanica (Sena Gomes and Kozlowski, 1980), Actinidia chinensis (Savé and Serrano, 1986), Taxodium distichum (Pezeshki et al, 1986), some of them having the reputation of being fairly tolerant to flooding. A few tested oak species like Quercus macrocarpa (Tang and Kozlowski, 1982), $Q$ falcata (Pezeshki and Chambers, 1985), and $Q \mathrm{mi}$ chauxii (Pezeshki and Chambers, 1986) behaved similarly. Most experiments were conducted with potted seedlings; however, Black (1984) showed that mature Quercus palustris in the stand showed the same stomatal reactions. Only a few reports of lack of stomatal closure with flooding are available (Alnus rubra and Populus trichocarpa; Harrington, 1987).

Was the limitation of $\boldsymbol{A}$ due to stomatal closure? In most cases decreases in $A$ and in $g$ presented a striking parallelism; but an analysis of the $A / c_{\text {; }}$ relationships led to the hypothesis that the observed limitations could only partly be attributed to stomatal closure. A non stomatal inhibition of photosynthesis probably occurred. Bradford (1983, Lycopersicon esculentum) and Pezeshki and Sundstrom (1988, Capsicum annuum) made the same assumption while observing that hypoxia promoted a reduction in $A$ at quasi-saturating $c_{i}$. However, the use of calculated values of $c_{i}$ in revealing non stomatal limitations of photosyn- 
thesis has been questioned (Downton et al, 1988; Terashima et al, 1988; Epron and Dreyer, 1990): artifacts due to patchy stomatal closure may appear. Heterogeneity of stomatal closure in response to waterlogging has not yet been tested. It may also be argued in favor of non-stomatal limitations that other workers have arrived at similar conclusions for waterlogging effects using different arguments. The fact that $A$ sometimes decreased without stomatal closure (Guy and Wample, 1984; with Helianthus annuus), and a study of ${ }^{13} \mathrm{C}$ isotopic discrimination (Guy and Wample, 1984) support the existence of a non stomatal limitation of $\boldsymbol{A}$ in flooded plants. In any case, a firm conclusion may only be obtained after careful analysis of leaf photosynthetic properties, for example by chlorophyll fluorescence techniques.

Stomatal closure in waterlogged plants has sometimes been attributed to reduced water potential, but predawn leaf water potential $\left(\Psi_{w b}\right)$ was not reduced by our treatments, even in the case of $Q$ rubra which showed severe damage to roots as described in Colin-Belgrand et al (1991). Leaf water potential has sometimes been reported to increase both in annuals (Bradford, 1983; Jackson and Hall, 1987) and in trees (Pezeshki and Chambers, 1985, 1986) due to reduced transpiratory losses following stomatal closure. Only a few reports have shown marked decreases in water potential (Zaerr, 1983; Osonubi and Osundina, 1987); such decreases have often been associated with anticipated shoot senescence and appeared long time after stomatal closure (Lewty, 1990). The water relations of flooded trees are nevertheless strongly affected by flooding; reductions in root hydraulic conductivity were observed by Harrington (1987, Alnus rubra) and appeared after a few hours in Populus trichocarpa $\times$ deltoides (Smit and Stachowiak, 1988). These reductions probably have only limited consequences on shoot water status because of reduced transpiration due to stomatal closure.

The trigger mechanism for stomatal closure and for hypothetical effects on mesophyll photosynthesis must therefore be independent of leaf water status. In the case of short term reactions to flooding, abscisic acid (ABA) which accumulates in leaf tissues may induce stomatal closure in the absence of a water deficit (Jackson and Hall, 1987). This ABA could be synthesized in root tips submitted to anoxia and transported to leaves via the transpiration flux (Zhang and Davies, 1987), but the time lags observed between stomatal closure and $A B A$ accumulation in leaves (Jackson et al, 1988) do not allow firm conclusion to be reached. Moreover, Smit and Stachowiak (1990) confirmed the existence of a factor promoting stomatal conductance in xylem sap, but did not observe increased ABA concentration in flooded Populus. There is still need for further research to identify the signal involved.

$Q$ robur showed very different responses to waterlogging in both experiments: strong decreases in $A$ and $g$ in the first, and almost no reaction in the second. This discrepancy was probably related to the depth of the unsaturated upper soil layer $(3 \mathrm{~cm}$ in the first experiment vs $6 \mathrm{~cm}$ in the second one). Lévy et al (1986) showed that sensitivity of $Q$ robur seedlings decreased markedly with a lowering of the water table, and disappeared below $8 \mathrm{~cm}$. $Q$ rubra, on the other hand, displayed very similar and strong reactions in both cases.

Were the observed decreases of $A$ and $g$ in $Q$ rubra and $Q$ palustris related to the observed root decay in these seedlings (Colin-Belgrand et al, 1991)? Correlations between root growth rate and net assimilation rates have been reported in transplanted seedlings (Guehl et al, 1989), even if 
the physiological link between both still has to be discovered. In $Q$ robur we observed a strong initial decay and subsequent new root growth; these 2 phases were not accompanied by any significant modification in $A$ or $g$.

An overall comparison of waterlogging tolerance between all tested species yielded the following results. In the first experiment, $Q$ petraea and $Q$ robur displayed approximately the same sensitivity, and $Q$ rubra was affected slightly more than the other species. In the second experiment, $Q$ robur was the least affected, while $Q$ rubra displayed the strongest reaction and $Q$ palustris had a somewhat intermediate behaviour (no decline, but a low initial $A$ and a divergence from the control sapling). The same ranking ( $Q$ robur / $Q$ palustris / $Q$ rubra) was obtained when considering the intensity of root reactions (Colin-Belgrand et al, 1991). This agrees well with observations made under natural conditions, where $Q$ petraea and $Q$ robur are known to be fairly tolerant, and $Q$ rubra very intolerant (Lévy et al, 1986).

The physiological basis of these differences has yet to be elucidated. The ability to form adventitious roots in the unsaturated soil layer is probably the major expression of these differences. This ability does not express a real tolerance to soil hypoxia; this is illustrated by the stronger reactions of $Q$ robur with higher water tables ( 3 vs $6 \mathrm{~cm}$ from the soil surface); complete flooding would be expected to induce even stronger reactions. There is still need for further experiments to test the effects of water tables at different depths in soils, and to compare the physiological reactions of various species.

\section{ACKNOWLEDGMENTS}

The authors wish to thank $P$ Gross for constructing the gas exchange device, JM Gioria for growing the seedlings and for preparing the experiments, and JM Guehl and 2 anonymous reviewers for helpful criticism on a first draft of the manuscript.

\section{REFERENCES}

Ball JT (1987) Calculations related to gas exchange. In: Stomatal Function (Zeiger, Fraquhar, Cowan, eds) Stanford University Press, 445-477

Black RA (1984) Water relations of Quercus palustris: field measurements of an experimentally flooded stand. Oecologia 64, 14-20

Bradford KJ (1983) Involvement of plant growth substances in the alteration of leaf gas exchange of flooded tomato plants. Plant Physiol $73,480-483$

Childers NF, White DG (1942) Influence of submersion of the roots on transpiration, apparent photosynthesis, and respiration of young apple trees. Plant Physiol 17, 603-618

Colin-Belgrand $M$, Dreyer $E$, Biron $P$ (1991) Sensitivity of seedlings from different oak species to waterlogging: effects on root growth and mineral nutrition. Ann Sci For 48 193-204

Davies FS, Flore JA (1986a) Short term flooding effects on gas exchange and quantum yield of rabbiteye blueberry (Vaccinium ashoi Reade). Plant Physiol 81, 289-292

Davies FS, Flore JA (1986b) Flooding, gas exchange and hydraulic root conductivity of highbush blueberry. Physiol Plant 67, 545551

Downton WJS, Loveys BR, Grant WJR (1988) Non-uniform stomatal closure induced by water stress causes putative non-stomatal inhibition of photosynthesis. New Phytol 110, 503-509

Guehl JM, Aussenac G (1987) Photosynthesis decrease and stomatal control of gas exchange in Abies alba Mill in response to vapor pressure deficit. Plant Physiol 83, 316322

Guehl JM, Aussenac G, Kaushal P (1989) The effects of transplanting stress on photosynthesis, stomatal conductance and leaf water potential in Cedrus atlantica Manetti seed- 
lings: role of root regeneration. In: Forest Tree Physiology (Dreyer E et al, eds). Ann Sci For 46 S, 464-468

Guy RD, Wample RL (1984) Stable carbon isotope ratios of flooded and unflooded sunflowers (Helianthus annuus). Can J Bot 62, 1770-1774

Harrington CA (1987) Responses of red alder and black cottonwood seedlings to flooding. Physiol Plant 69, 35-48

Jackson MB, Hall KC (1987) Early stomatal closure in waterlogged pea plants is mediated by abscisic acid in the absence of foliar water deficits. Plant Cell Environ 10, 121-130

Jackson MB, Young SF, Hall KC (1988) Are roots a source of abscisic acid for the shoots of flooded pea plants? J Exp Bot 39, 16311637

Jones HG (1985) Partitioning stomatal and non stomatal limitations to photosynthesis. Plant Cell Environ 8, 98-104

Lévy G, Becker M, Garreau B (1986) Comportement expérimental de semis de chêne pédonculé, chêne sessile et hêtre en présence d'une nappe d'eau dans le sol. Ann Sci For $43,131-146$

Lewty MJ (1990) Effects of waterlogging on the growth and water relations of three Pinus taxa. For Ecol Manage 30, 189-201

Osonubi O, Osundina MA (1987) Stomatal responses of woody seedlings to flooding in relation to nutrient status in leaves. $J$ Exp Bot 38, 1166-1173

Newsome RD, Kozlowski TT, Tang ZC (1982) Responses of Uimus americana seedlings to flooding of soil. Can J Bot 60, 1688-1695

Peterson DL, Bazzaz FA (1984) Photosynthetic and growth responses of silver maple (Acer saccharinum $\mathrm{L}$ ) seedlings to flooding. $A m$ Mid Natur 112, 261-272

Pezeshki SR, Chambers JL (1985) Responses of cherrybark oak seedlings to short term flooding. For Sci 31, 760-771

Pezeshki SR, Chambers JL (1986) Variation in flood induced stomatal and photosynthetic responses of three bottomland tree species. For Sci 32, 914-923
Pezeshki SR, Delaune RD, Patrick WH Jr (1986) Gas exchange characteristics of bald cypress (Taxodium distichum $L$ ): evaluation of responses to leaf aging, flooding and salinity. Can J For Res 16, 1394-1397

Pezeshki SR, Sundstrom FJ (1988) Effect of soil anaerobiosis on photosynthesis of Capsicum annuum L. Scientia Hort 35, 27-35

Regehr DL, Bazzaz FA, Boggess WR (1975) Photosynthesis, transpiration and leat conductance of Populus deltoides in relation to flooding and drought. Photosynthetica 9, 5261

Savé R, Serrano L (1986) Some physiological and growth responses of kiwi fruit (Actinidia chinensis) to flooding. Physiol Plant 66, 7578

Sena Gomes, Kozlowski TT (1980) Growth responses and adaptations of Fraxinus pennsylvanica seedlings to flooding. Plant Physiol $66,267-271$

Smit BA, Stachowiak ML (1988) Effects of hypoxia and elevated carbon dioxide concentration on water flux through Populus roots. Tree Physiol 4, 153-165

Smit BA, Stachowiak ML (1990) Rot hypoxia reduces leaf growth. Role of factors in the transpiration stream. Plant Physiol 92, 1021. 1028

Tang ZC, Koslowski TT (1982) Some physiological and morphological responses of Quercus macrocarpa seedlings to flooding. Can J For Res 12, 196-202

Terashima I, Wong SC, Osmond CB, Farquhar GD (1988) Characterisation of non uniform photosynthesis induced by abscisc acid in leaves having different mesophyll anatomies. Plant Cell Physiol 29, 385-394

Wample RL, Thornton RK (1984) Differences in the response of sunflowers (Helianthus annuus L) subjected to flooding and drought stress. Physiol Plant 61, 611-616

Zhang J, Davies WJ (1987) ABA in roots and leaves of flooded plants. $J$ Exp Bot 38, 649659

Zaerr JB (1983) Short-term flooding and net photosynthesis in seedlings of three conifers. For Sci 29, 71-78 